$10-2006$

\title{
Access to Justice, Costs, and Legal Aid
}

James P. George

Texas A\&M University School of Law, pgeorge@law.tamu.edu

Follow this and additional works at: https://scholarship.law.tamu.edu/facscholar

Part of the Law Commons

\section{Recommended Citation}

James P. George, Access to Justice, Costs, and Legal Aid, 54 Am. J. Comp. L. 293 (2006).

Available at: https://scholarship.law.tamu.edu/facscholar/442

This Article is brought to you for free and open access by Texas A\&M Law Scholarship. It has been accepted for inclusion in Faculty Scholarship by an authorized administrator of Texas A\&M Law Scholarship. For more information, please contact aretteen@law.tamu.edu. 


\section{Access to Justice, Costs, and Legal Aid}

If the ideal of justice is not pervasive in the United States, the issue of justice is-not so much in its rendition, but in its penetration of news, politics and entertainment. Current media issues include the death penalty-erroneous convictions and the lack of lawyers for appeals ${ }^{1}$; tort reform-conflicting data on medical malpractice litigation $^{2}$ and a perceived abuse of class actions; and the judiciary itselfjudicial selection, political attacks on so-called "activist judges,"3 and the sometimes hidden issue of court budgets. Within this fascination, the multiple problems in accessing justice are lost.

Legal news becomes entertainment with the periodic carnival of celebrity criminal trials which cluster like natural disasters. Taking a half-step back to fictional accounts, television programming in the United States presents the irony of numerous series concerning lawyers and/or law enforcement, but dealing little with access to the system it depicts. CSI (for Crime Scene Investigation) is a police drama about forensic work and was American television's top-rated show for the 2002-03 and 2003-04. For the week June 20-26, 2005, the top 20 broadcast television shows included eight crime or court-related shows, ${ }^{4}$ likely with no mention of access issues. To the contrary, these shows create the impression that litigants have lawyers as a matter of course and that courts are readily available within the hour.

Justice-as-politics is another aspect of entertainment. Wrenching public policy questions parade in front of us, yet political plat-

* Professor of Law, Texas Wesleyan University School of Law. For their valuable input, I thank Jack Coe, Jim Cuaderes, Lawrence Friedman, Steve Hayes, David Hyman, Andrew Spiropoulos, Justice Sue Walker; my colleagues Wendy Law and Anna Teller, my research assistants Morad Fakhimi, Scott Petty and Nikki Wood, and the helpful people at the National Center on State Courts and the Administrative Office at the United States Courts.

1. Crystal Nix Hines, Lack of Lawyers Hinders Appeals in Capital Cases, N.Y. Times, July 5, 2001 at A1.

2. Joseph V. Treaster, Malpractice Insurance: No Clear or Easy Answers, N. Y. Times, March 5, 2003 at C1 (casts doubt on American Medical Association's findings that damage caps will hold down the sharply rising cost of malpractice insurance).

3. Ron Chernow, Chopping Off the Weakest Branch, N. Y. Times, May 6, 2005 at A23 (editorial concerning coordinated attacks on the judiciary by conservative politicians and conservative religious leaders).

4. See http://nielsenmedia.com/ratings/broadcast_programs.html (last checked July 3,2005$)$. 
forms only vaguely refer to justice. The 2004 Republican Party platform in its defense of exclusive heterosexual marriage attacked the judiciary ${ }^{5}$ while the Democrat's platform was silent on justice. ${ }^{6}$ Missing in both platforms is any overt reference to the more widespread problems in access to justice. Access to legal services for indigents and middle-income people has not been a significant issue, although the Legal Services Corporation remains under attack. A larger political issue has been the flip side of access to justice-the perception that lawyers and the legal system have undermined health care, the manufacturing sector, and other vital American interests. This issue has played out not only in legislatures capping damage awards and in some cases eliminating legal remedies, but in increased regulation of attorney fees and more recently, political attacks on the judiciary. The assault on the judiciary includes sharp funding cuts for court operation in both the state and federal systems, and on the state level only, denials of judicial pay raises. ${ }^{7}$

This article is excerpted from a report done for the 17 th International Congress of Comparative Law, a quadrennial convention of lawyers and scholars. The full report on the United States is 47 pages, responding to questions posed by Professor Ugo Mattei to reporters from several countries. Space limitations for this symposium issue required the omission of much of the study, but readers wanting a copy of the full report may obtain it from the author. ${ }^{8}$ The selections here highlight the so-called litigation explosion in the United States and the costs of maintaining its court systems, with abridged

5. Under the heading "Protecting Our Families," the platform states: "President Bush said, 'We will not stand for judges who undermine democracy by legislating from the bench and try to remake America by court order." See www.gop.com/media/ 2004 platform.pdf at page 84. The platform then mentioned the Republicans' support for an amendment to the Defense of Marriage Act. 28 U.S.C.A. $\$ 1738 \mathrm{C}$ (West Supp. 2005). The original act denied full faith and credit status to any one state's judicial finding in support of same-sex marriage, and the amendment-now termed the Marriage Protection Act of 2005, H.R. 1100 -strips federal courts of jurisdiction to consider the original act's constitutionality. The bill is currently in subcommittee. See http://thomas.loc.gov.cgi-bin/bdquery/z?d109:h.r.01100:. The platform continues: "We urge Congress to use its Article III power to enact this into law, so that activist federal judges cannot force 49 other states to approve and recognize Massachusetts' [sic] attempt to redefine marriage." See www.gop.com/media/2004platform.pdf at page 84 .

6. See www.dems2004.org. The current Democratic Party website endorses one aspect of access to justice in its support of "Civil Rights and Justice" but offer no specifics. See http://www.democrats.org/agenda.html.

7. See infra note 54 .

8. My email is pgeorge@law.txwes.edu. Topics raised in Professor Mattei's questionnaire but omitted here include the stigma to suing or being sued; the principal of innocence until proven guilty as limiting the stigma for criminal defendants; the structure of attorney fees; the costs of litigation to the consumer; the costs of specific lawsuits; legal insurance; pro bono practice; public interest law firms; sources for consumers obtaining legal advice; the use of criminal litigation as a substitute for civil litigation; victims' rights in the criminal process; victims' prosecution of crimes; and additional information on legal aid for low income clients. 
discussions of other topics such as the consumer's costs in litigating and legal services for low income clients.

\section{The Institutions of Justice}

Any attempt to measure justice or its access must start with the institutions cloaked with the power to render justice. Since the elimination of tribal and feudal courts, the Anglo-American system has depended on courts of law for the resolution of private disputes, and increasingly for public disputes. But the law courts' dominance has been periodically modified and even preempted by alternative systems such as equity, and more recently arbitration and other forms of dispute resolution that offer, or at least purport to offer, significant alternatives to traditional courts. The United States today uses a number of these systems both to supplement and in some cases replace litigation. In measuring access, these institutions could be examined on any number of issues; this study will focus on two crucial issues - the volume of business in the courts and the costs of maintaining courts as our primary means of resolving disputes.

\section{A. Courts}

Courts in the United States are divided into state and federal systems in which state courts are the courts of general jurisdiction and federal courts have limited jurisdiction as outlined in the United States Constitution and further specified by Congress. Federal courts are organized into 91 districts exercising trial and some appellate jurisdiction, 13 intermediate courts of appeal, and one Supreme Court. In addition, Congress has created a number of other specialized tribunals which adjudicate such matters as bankruptcy cases, contract claims against the government, appeals from administrative agency decisions, and disputes in United States territories. ${ }^{9}$ Most states court systems mirror the federal system with trial-level courts, intermediate appellate courts and a single high court, although variations exist. ${ }^{10}$ State court systems also have lower-level trial courts with jurisdiction limited both by subject matter and amount in controversy; these are often denominated as county courts and small claims courts. ${ }^{11}$ Many Indian tribes maintain courts with limited ju-

9. See generally Charles A. Wrigh'T \& Mary Kay Kane, The Law of Federal Courts 6th ed. (2002) Chaps. 1-6; James P. George, The Federal Courthouse Door (2001) 1-32.

10. Some states have no intermediate appellate courts, and two statesOklahoma and Texas-have twin high courts exercising civil and criminal jurisdiction.

11. In some but not all jurisdictions, small claims judges must be licensed attorneys. Another distinction from district courts and county courts is that small claims courts are, in most states, not courts of record. That is, there is no court reporter recording the proceedings. Where appeal is available from these courts, it is often an 
risdiction over a variety of matters such as family law and criminal offenses. ${ }^{12}$

\section{Court Usage}

a. Percentage of the population as plaintiff or defendant: Reliable estimates for this are nearly impossible because of the variety of lawsuits and the varying number of parties in each suit, ranging from one plaintiff and one defendant to thousands of parties. The most recent data available for both state and federal litigation is for the year 2002. In that year, there were $97,887,356$ actions filed in state trial courts (or courts of the first instance). In the same year, there were 1,835,412 actions filed in federal district courts. Thus, in 2002 the total number of suits filed in state and federal courts in the United States was 99.72 million. The 2000 census estimated the United States population to be $281,421,906$ as of April 1,2000. With this rough comparison of 2002 filings to the 2000 population, there were a little under 100 million legal actions filed in state and federal courts in 2002 for a population somewhat over 281 million. This number fails to account for the number of parties in each suit, and for the number of disputes with parallel or multiple filings (that is, $P$ sues $D$ who in turn sues $P$ for a mirror-image claim in a second court). ${ }^{13}$

b. The number of lawsuits: A litigation explosion is widely perceived in the United States, and as with other issues, the data can be read to support diametrically opposed positions that (1) Americans are the most litigious people on earth, and alternatively (2) we're about average. ${ }^{14}$ Some attempt at objectivity may be had by looking at the numbers compiled by courts, although the numbers below are only the briefest sketch of the data compiled and compared by the state and federal judiciaries. In regard to state court litigation, the most recent data measures the period from 1993 to 2002, showing that during that time: (1) civil cases increased by 14 percent in state courts of general jurisdiction, and by 10 percent in state courts of limited jurisdiction; (2) domestic relations cases increased by 14 percent;

appeal de novo in the district court. This means that the "appeal" is not a review of a trial record (because there is none), but is instead a new trial.

12. See generally Robert N. Clinton et al., American Indian Law: Native NaTIONS AND THE FEDERAL SYSTEM 4th ed. at 339-43 (2003). For a focused discussion of one tribe's judicial experience, see RenNard Strickland, Fire and the SpIrits: CherokeE LAW FROM Clan to Court (1975).

13. For state court data, see http://www.ncsconline.org. For federal court data, see ww'w.uscourts.gov.

14. See John Cochran, A Simple Case of Complexity, CQ WeEkLy, January 31, 2005 at 230 (hereinafter A Simple Case of Complexity). Critics were condemning the litigation explosion twenty years ago, and their accuracy then, too, was questionable at best. See Lawrence M. Friedman, Total Justice: What Americans Want from THE Legal System AND Why (1985) at 15-23 (hereinafter Total Justice). 
and (3) criminal cases increased by 19 percent. Combined civil, criminal and domestic relations cases have grown 15 percent from 1993 to 2002. Traffic prosecutions are the largest segment ( 60 percent of all filings) and they've remained constant, with a two percent increase from 1993 to 2002 . Thus the 15 percent growth was in civil, domestic and non-traffic criminal. ${ }^{15}$ In an interesting though dated comparison of state and federal caseloads, a 1993 study found that state courts of general jurisdiction handled 85 times as many criminal cases and 27 times as many civil cases as federal courts, but with only 14 times as many judges. ${ }^{16}$ This comparison is misleading, though, because of the significant difference in case complexity between state and federal courts. All cases in federal court involve either breaches of federal law or non-federal claims exceeding $\$ 75,000$, with most federal lawsuits having claims far higher, making not only the trial but the pretrial discovery phase far more complicated. In addition, federal judges must commit more to a written record than state judges.

Federal litigation has also increased, owing both to Congress's expansion of federal jurisdiction and the growing American and global economy. In fiscal year 2004 (FY 2004) district court filings increased nine percent, with 281,338 civil filings (an 11.2 percent increase over FY 2003), and criminal filings remaining roughly even with 71,022 filings (up .5 percent over FY 2003). ${ }^{17}$ Bankruptcy filings fell 2.6 percent this year, but remain high at $1,618,987$, up 83.3 percent from FY 1995. ${ }^{18}$ Although the new bankruptcy act President Bush signed on April 20, 2005, may lower filings over time, the immediate result no doubt will be a spike in filings to clear the proposed act's effective date, scheduled in the current bill for 180 days after the act's adoption. ${ }^{19}$ For the courts of appeals, FY 2004 was the tenth consecutive year of increases with 62,762 appeals filed, up 3.1 percent over FY 2003 and up 25 percent in the past decade. ${ }^{20}$ More significantly, the appellate courts are slowing in case resolution, with cases pending at the end of FY 2004 up 14.3 percent from FY 2003. ${ }^{21}$ Since 1990 - the date of the most recent comprehensive federal judgeship bill—no new federal appellate judgeships have been created

15. See Examining the Work of State Courts-2003, available at www. ncsconline.org.

16. See Caseload Highlights,Volume 1, Number 1, available at www.ncsconline. org.

17. See Judicial Business of the U.S. Courts-2004 at 11 (found at http://www.us courts.gov/judbus2004/contents.html).

18. Id.

19. Bankruptcy Abuse Prevention and Consumer Protection Act of 2005, 109th Congress, 1st Session, Jan. 7 2005, Pub.L. 109-8 (S-256), Apr. 20, 2005, 119 Stat. 23, effective July 1, 2005.

20. Id.

21. Id. 
even though the appeals docket has grown by 46 percent in that time, while in the same period, 34 new federal district judgeships were created to meet a 39 percent docket increase. ${ }^{22}$

In considering the current budget shortages for federal courts, a more important pictures emerges in examining the past 20 years. From 1960 to 2004 , civil filings increased from 59,284 to 281,338 (475 percent) while the number of judges increased from 245 to 679 (277 percent). ${ }^{23}$ From 1977 (this second table's starting year) to 2004, civil filings increased from 133,929 to 281,338 (210 percent); during this time federal question filings increased 284 percent (from 58,083 to 165,241 ) while diversity filings increased at the lesser rate of 213 percent (from 31,735 to 67,624 ), ${ }^{24}$ showing not only growth, but that growth is more attributable to Congress's federalization of the law than it is to diversity litigation. ${ }^{25}$

Whether these figures for state and federal courts amount to a litigation explosion is difficult to say. The state courts' collective caseload greatly exceeds that of the federal courts with a significantly small judge to case ratio. On the other hand, federal courts are quickly catching up. Filing increases in state court do not appear to exceed population growth (15 percent increase in 10 years), while those in federal court do (475 percent increase in 45 years). In his 1983 book Total Justice, Professor Lawrence Friedman cites several studies showing that contrary to popular belief, Americans have about the same litigation rate as other industrialized countries, and that significant aberrations exist-both high and low-in other countries. $^{26}$

c. The appeal rate: For state courts, the National Center for State Courts issued its most recent report in 2003, based on 2002 data. The NCSC does not track the filings of appeals linked to the original filing in the trial court. ${ }^{27}$ For 2002, the NCSC reports that 95.9 million actions of all types were filed in state courts of original jurisdiction, and that in the same year, 297,000 appeals were filed in state courts.

22. Administrative Office of the United States Courts News Release: Conference Calls Off-Site Security for Judges Top Priority, March 15, 2005, at 2 (found at www.us courts.gov/Press_Releases/index.html) (herinafter Off-Site Security).

23. Table 2.11, U.S. District Courts, Civil Cases Filed, Terminated, Pending (found at http://uscourts.gov/judicialfactsfigures/table2.11.pdf).

24. Table 2.01, U.S. District Courts, Civil Cases Filed, Terminated, Pending (found at http://uscourts.gov/judicialfactsfigures/table2.11.pdf).

25. See American Bar Assoc., The Federalization of Federal Criminal Law, (James Strazella, Reporter, 1998) at 10 (available at http://www.abanet.org/crimjust/ fedreport.html; or can be purchased at ababooks.org).

26. See Deborah Rhode, Access to Justice (2004) at 29-30 (hereinafter Access TO JUSTICE); TOTAL JUSTICE, supra note 14 at 15-23.

27. The apparent reason is that district court actions filed in any given year will not all reach final judgment in the same year, thus requiring a case-by-case tracking linked both to the filing year and the appeal year, which is no doubt difficult. Instead the NCSC tracks the number of filings in the various state appellate courts in a given year, grouped by civil and criminal appeals. 
This works out to a .003 appeal rate, or three-tenths of one percent of the total cases filed. Note, however, that of the 95.9 million cases filed, 57.7 million were traffic-related (not including civil claims for traffic accidents). When limited to civil, domestic relations, criminal and juvenile actions filed, the number is $\mathbf{3 8 . 5}$ million. Assuming that the vast majority of appeals came from this smaller pool, the appeal rate is .007 , or .07 of one percent.

Federal appeals are more difficult to track. In a practice identical to that of the National Center for State Courts, the Administrative Office of the United States District Courts (the "AO") does not specifically track percentage of cases appealed. As explained above, the likely reason is that district court actions filed in any given year will not reach final judgment in the same year, thus requiring a caseby-case tracking linked both to the filing year and the appeal year, which is apparently too difficult. Instead the AO tracks the number of filings in the Circuit Courts of Appeal in a given fiscal year (grouped by administrative appeals, criminal appeals, civil appeals, and original actions). In FY 2004, criminal appeals increased by four percent (up to 12,506) and civil appeals fell four percent (down to 33,075 ). In all appellate filings (including administrative appeals and original actions), criminal appeals accounted for 20 percent of the appellate caseload. Note that prisoner habeas appeals are tallied as civil actions, and in FY 2004 there were 1,130 filed.

In spite of the federal court AO's failure to track percentage of cases appealed, we may estimate the number as follows. In FY 2004, there were 352,360 total filings in federal district court (281,338 civil and 71,022 criminal). In the same FY 2004, there were 62,762 filings in the Circuit Courts of Appeal (the Administrative Office of United States Courts does not break them down for civil and criminal). ${ }^{28}$ If the FY 2004 appeal filings were all from a year similar to the FY 2004 district court filings, this would be a $\mathbf{1 7 . 8}$ percent appeal rate. Of course this result is likely inaccurate because the FY 2004 appeals were drawn from earlier years' district court filings, and not all in the same year. Noting that district court filings increase nine percent from FY 2003 to FY 2004, it may be assumed that the appeal filings were drawn from a somewhat smaller district court pool than the one in FY 2004, thus pushing the 17.8 percent up, perhaps to 20 percent. This number also fails to account for how many civil cases were appeal and how many criminal.

d. The settlement rate: In its 2003 report (based on 2002 data), the National Center for State Courts reported that for a ten state study (based on states that reported comparable data), that seven percent of the civil cases resulted in a jury trial or bench trial. The remaining 93 percent of the caseload is not distinguished between

28. See supra note 17. 
voluntary dismissal, involuntary dismissal, and summary judgment, or agreed judgment (where settlements would most likely be accounted for in the voluntary dismissals and the agreed judgments). The Administrative Office for the Federal Courts does not keep separate data on this.

\section{Court Efficiency}

However accessible courts may be for filing claims and issuing process, however affordable the attorneys, and however convenient the procedural rules for the pro se litigant, the delivery of justice is compromised by an inefficient system. Efficiency may be measured in any number of ways, but two important measures are court delays, and the ability of the system to compensate victims and assess the costs against wrongdoers and not innocent third parties. The American system has a mediocre score on the first and a lower score on the second.

a. Justice delayed: Litigation delays are the subject of complaint but are difficult to measure. We may speculate that they are becoming more common because of the increased complexity of litigation and because of legislative short-funding in both in state and federal courts. Neither the state nor the federal systems collect date on time from filing to resolution. For federal courts, however, we may get a hint by measuring the case backlog, tracked as "cases terminated" versus "cases left pending." At the close of FY 2004 there was an 11.1 percent increase in the number of civil cases pending and a 10.8 percent increase in criminal cases pending, over the number for FY 2003. In addition, FY 2004 was the first time in five years that the federal district courts terminated fewer cases in the year than those left pending; for civil cases, federal courts have terminated fewer cases than those left pending for the past four years. If this depicts a trend, then the backlog is growing.

Unlike the federal court system, state courts have no collective data on pending cases at the end of calendar or fiscal years. This leaves almost no means of measuring the composite state court system, and I'm not aware of any published data for individual states, though some no doubt collect it. In 2001, the National Center for State Courts published a study entitled Caseload and Timeliness in State Supreme Courts, measuring various aspects of high appellate resolution in five states. The study concluded that the studied states' supreme courts were reasonably timely overall, but with significant variations explained in part by the variety of their respective caseloads. $^{29}$

29. See Caseload and Timeliness in State Supreme Courts, Caseload Highlights, Vol. 7, No. 2, available at www.ncsconline.org. 
b. Efficiency of the civil and/or criminal justice system apart from delays: For the question, is the civil/criminal justice system considered efficient, at least by the public, the answer depends on whom your ask, but will often be "no." On the question of whether it is efficient, the answer depends on which efficiencies we are measuring. On the issue of the overall cost/benefit ratio, there are arguments on both (or several) sides, as reflected elsewhere in this article. But if we narrow efficiency to whother the system rewards the victim and accurately imposes the costs on the wrongdoer, the answer in too many instances is "no." In what may be one of the more reliable studies (gathered by law professor David Hyman but based on data generated by medical schools), the evidence paints a bad picture of the American legal system's efficiency:

-about four percent of hospital patients suffer an adverse event, 50 percent of which are preventable and 25 percent of which are caused by negligence;

-thus, one percent of hospital patients are victims of negligence, with consequences ranging from complete recovery within one month ( 46 percent of those injured) to death (25 percent of those injured), amounting to an estimated 200,000 deaths yearly in the United States caused by medical negligence;

-about two percent of those negligently injured file a claim, with the percentage increasing as the severity of the injury increases;

- while only a small number of the truly injured patients sue, a substantial majority of the suits filed involved no negligence and/or no injury;

- comparing the two, the second problem is dwarfed by the first-for every invalid claim filed, seven valid claims go unfiled;

- for the cases filed, the best predictor of the size of the award is the severity of the disability, not the presence of negligence (although Professor Hyman does not explain how the study determined that the judge or jury got it wrong);

-for every dollar that goes to an injured patient or the heirs, two dollars are spent getting it there. ${ }^{30}$

30. See David A. Hyman, Medical Malpractice and the Tort System: What Do We Know and What (If Anything) Should We Do About It? 80 TEx. L. REv. 1639, 1643-44 \& notes 8-14 (2002) (based on data from various articles in the New England Journal of Medicine and other medical journals). The medical studies determined the validity of claims based on a three-person panel's review of evidence, as reported in the studies. 
No matter what reforms are implemented, the task of making the system efficient without sacrificing justice may be problematic. However, to the extent that negative studies blame the law or lawyers for these results, Lawrence Friedman's point is well taken that lawyers did not create the current system, but merely responded to the advances in science and technology, and to societal demands. ${ }^{31}$ That is not to say that lawyers aren't part of the problem (for example, with frivolous lawsuits), but only that lawyers did not create the science that made negligence law possible.

c. Eliminating nuisance suits: It is axiomatic that defendants have inherent burdens in being defendants. The burdens vary with the case, influenced by:

-The lawsuit's complexity, including the nature of the claim (antitrust claims are more complex than most breaches of contract); the number of additional parties; the need to assert counterclaims or crossclaims;

-Defendants resources relative to this complexity;

-Discovery (both plaintiff's and defendant's) which even in a simple two-party lawsuit may be expensive, intrusive and time consuming;

-The supersedeas bond in the event defendant loses at trial and wishes to appeal; ${ }^{32}$

- Concerns about later liability because of preclusion, thus increasing the need to put up a strong defense.

Scientific and technological improvements-photocopiers, word processors, email, demonstrative evidence-have increased these burdens in recent decades, but to the extent a defendant finds itself in a legitimate dispute, the burdens are unfortunate but for the most part necessary. A significant problem is the frivolous or nuisance lawsuit, aimed at nothing more than coercing a settlement in order to avoid these burdens. Nuisance suits are those lacking merit, either because the defendant has suffered no compensable damage or because the defendant did not cause it. The motive in filing the suit is the hope of negotiating a "nuisance-value" settlement, which may be anywhere from a few thousand dollars for a routine lawsuit, up to

31. See Total Justice, supra note 14 at 70-72.

32. Some states require defendants who have lost at trial to post a security bond for the full judgment plus the estimated interest in order to stay judgment enforcement pending appeal. Texas followed this practice and its burdensome nature became apparent in Pennzoil's well-publicized claim against Texaco, in which Texaco claimed an inability to post a $\$ 13$ billion bond. See Pennzoil Co. v. Texaco, Inc., 481 U.S. 1 (1986); see also Bishop \& Sarles, Supersedeas Bonds A Crushing Burden, NAtional Law Journal, Nov. 13, 1995 at C25. Texas has since amended its bond requirement to cap them at the lower of $\$ 25$ million or fifty percent of the defendant's net worth, and to allow for hearings to challenge any other burdens that might arise. See Tex. Civ. Prac. \& Rem. Code $\$ 52.006$ (Vernon Supp. 2004-05). 
several tens of thousands of dollars for more complex cases. Nuisance value may be determined by any means the parties choose, but is often based on defendant's estimated costs in preparing for and going through trial. Some critics of the current American system believe the nuisance settlement has done more real harm to the American legal system than the more disputed claims about runaway juries. ${ }^{33}$ The nuisance settlement must be distinguished from settlements in which defendant firmly denies liability and may indeed feel blameless, but nonetheless pays a large portion of plaintiff's claim based on defendant's estimate of the chances of being found liable. Although these defendants may come away from the case angry, few if any advocates of tort reform are arguing overtly on their behalf. On the other hand, much of the results of tort reform will benefit these defendants just as much as those who are victims of the nuisance suit.

One other aspect of nuisance litigation-seldom if ever written about-is the nuisance defense, raising frivolous arguments throughout the pretrial phase and possibly into the trial or appeal. Some defense lawyers and clients will argue that this is no more than conducting a proper defense, that is, pursuing an argument until the evidence demonstrates its falsity. But the same can be said of the frivolous plaintiff's claim. Although plaintiff or any opposing party may ask the court to eliminate frivolous claims early in the case, many courts are reluctant to act until discovery is concluded. Because frivolity deals more with grays than blacks and whites, this problem is not easily resolved. It is nonetheless a factor in the nation's litigation costs.

\section{B. Alternatives to Courts}

Alternative Dispute Resolution (ADR) schemes vary among jurisdictions, as do the requirement for the people administering them. The most common, along with their qualifications, are arbitration, collaborative law, ${ }^{34}$ judicial settlement conferences, mediation, ${ }^{35}$ the

33. See Testimony of Andrew Spiropolous before the Oklahoma Council of Public Affairs, found at http://www.ocpathink.org/ViewResearchAndIdeasStory.asp. See also ACCESS TO JUSTICE, supra note 26 at 24-29, 33, 194. In a class action regarding silicosis claims, a Texas federal judge recently dismissed a significant number of claimants and accused plaintiffs' lawyers and doctors of offering unreliable diagnoses. See Mike Tolson, Attorneys Behind Silicosis Suits Draw U.S. Judge's Wrath, Houston Chronicle, July 1,2005 at A1.

34. Collaborative processes are often used in divorce. The parties agree not to litigate and instead conduct a series of meetings that are more involved that mediation, and involve counsel, experts and others, with everyone committed to reaching a solution. See generally Kay Elkins Elliott \& Frank Elliott, eds., Alternative Dispute Resolution Handbook (State Bar of Texas ADR Section, Imprimatur Press, 2003) (hereinafter "ADR HANDBOOK").

35. Mediation is the parties' attempt to reach an agreement with the help of a mediator-a "third party neutral" who serves to facilitate communication and negoti- 
mini-trial, ${ }^{36}$ the moderated settlement conference, ${ }^{37}$ negotiation, and private judging. ${ }^{38}$

ADR clauses are now included in many standard contracts with banks, insurance companies, utilities providers, and so on. Whether the clause is binding, that is, whether the other party may ignore it and sue, depends both on the clause's drafting and the nature of the contract. Properly drafted arbitration clauses that indicate the parties agreement for mandatory arbitration (that is, they exclude litigation), are enforceable in both state and federal courts in the United States, subject to exceptions such as waiver, and statutory exceptions for certain contracts. ${ }^{39}$

Some states build arbitration schemes into statutory remedies, such as the new Texas law regarding warranty claims on new home construction..$^{40}$ States may require mediation or negotiation as a prerequisite to certain remedies. ${ }^{41}$ Where state law does not address

ation and not to make an fact or legal findings in the dispute. Mediators in general have no training or certification process in most states, except for court-ordered mediation, which often requires licensing. Under Texas law, court annexed mediation requires a mediator who has completed forty hours of classroom training from a group approved by the court; family mediation requires an additional twenty-four classroom hours. See Tex. Civ. Prac. \& Rem. Code $\$ \$ 154.052(a)$ - (c) (Vernon 2005).

36 . The mini-trial is non-binding, similar to a summary jury trial, but conducted in private and argued not to a judicial functionary, but to the parties themselves; Mini-trials are argued by the parties' counsel, and argued to the parties themselves; thus the only required training is to be in a dispute. A variation on this is the summary jury trial-a shortened trial with non-binding results that will give the parties a jury's perception and thereby facilitate negotiations. See Judge Thomas D. Lambros, The Summary Jury Trial and other Alternative Methods of Dispute Resolution: A Report to the Judical Conference of the United States Committe on the Operation of the Jury System, 103 F.R.D. 461 (1984).

37. This is a private, nonbinding process in which the litigants and their attorneys meet with a private panel of three attorneys who evaluate the case. Moderated settlement conferences typically use a panel of three attorneys. See ADR HANDBOoK, supra note 34 at $119-34$.

38. Private judging is a binding non-jury trial for which a retired judge is hired. Private judges's qualifications vary, but many states require judicial experience. Texas, for example, requires that "special judges" be retired district, county, or appellate judges who served as judges for at least four years. See Tex. Civ. Prac. \& Rem. Code $\$ \S 151.001$ et seq. (Vernon 2005); see also Cal. Const. Art. 6, § 21; Cal. Civ. P. Code $\$ 638$ (West Supp. 2005).

39. See the Federal Arbitration Act, 9 U.S.C.A. \& 4 (West 1994); Dean Witter Reynolds, Inc. v. Byrd, 470 U.S. 213 (1985). The Federal Arbitration Act, for example, applies to most employment agreements but exempts contracts involving interstate transportation workers. See Circuit City Stores Inc. v. Adams, 532 U.S. 105 (2001). The Magnuson-Moss Warranty Act pre-empts binding arbitration clause in consumer sales contracts. See Wilson v. Waverlee Homes, Inc., 954 F. Supp. 1530 (M.D. Ala. 1997). See generally Bette J. Roth, et al., 1 Altrernative Dispute Resolution PraCTICE GUIDE at $\S 6.2$ (2004).

40. See Texas Residential Construction Commission Act, Tex. Prop. Code $\S \S 436.001-.004$ (Vernon Supp. 2005).

41. Some state remedies, particularly for consumer claims, required a "cooling off" period during which negotiation must be attempted. The Texas Deceptive Trade Practices and Consumer Protection Act, for example, requires consumers to provide notice to the prospective defendant sixty days prior to filing a lawsuit, and during 
ADR, courts may insist on some schemes including mediation, negotiation and the judicial settlement conference. Others occur on the parties' initiative, including the mini-trial and the collaborative process. Some-arbitration in particular-are used as alternatives to litigation, and have become common both in routine disputes such as credit card claims and homeowner's warranty claims against the builder, and in larger cases such as employment (both individual employment complaints and large labor disputes), environmental cases and commercial disputes. ADR has also found its way into criminal cases. In many states, people claiming to be crime victims are encouraged (and the defendant may be required) to mediate. ${ }^{42}$ Other ADR schemes, such as using a special judge or conducting a mock trial, are voluntary.

\section{The Costs of Courts}

The broader report from which this section is drawn looks in detail at both micro and macro costs, that is, the costs to the consumer for filing and paying other fees during litigation and arbitration, and the taxpayer costs of financing the judicial and prosecutorial system. This article briefly summarizes individual consumer costs and focuses on court funding.

\section{A. Micro Costs-The Impact on the Legal Consumer}

Court costs in the United States have a very rough uniformity. One plaintiff suing one defendant in a district court (state or federal) must pay from $\$ 100$ to $\$ 200$, with personal service of summons by a sheriff typically costing $\$ 50$ to $\$ 100$. Small claims courts tend to have lower filing fees but similar service-of-process fees, although a lower-cost service by mail is usually available for all courts. Later fees can include a jury fee, exhibit fees, an appeal bond, a supersedeas bond to secure the judgment (and stop execution) pending appeal, court reporter fees for the trial transcript, fees for abstracting and executing on the judgment, and a number of costs during discovery for court reporters, audio-visual crews, and so on. Some of these fees may be waived for low income litigants. Most jurisdictions post

that time, to make the goods available for inspection, Tex. Bus. \& Comm. Code $\S 17.505$ (Vernon 2002); gives defendant a right to compel mediation within ninety days of the suit's filing, id. at $\S 175051$; and has an "offer-of-settlement" provision that allows defendant to make a reasonable offer and thereby limit plaintiff's recovery of damages, attorney fees and costs, id. at $\S 17.5052$.

42. See Tex. Code Cr. Proc. art. 56.13 (Vernon Supp. 2004-05), which authorizes the Texas Department of Criminal Justice to train mediators and provide mediation services between victims or their relatives and the offender whose criminal conduct caused bodily injury or death. See also www.tdjc.state.tx.us/victim/victim-vomd.htm. 
these fees on their websites, as does the American Arbitration Association. ${ }^{43}$

\section{B. Macro Costs-the Impact on the United States Government and the Economy}

$C Q$ Weekly, published by Congressional Quarterly, reported that, "With the 'tort reform' battle long on hype and short on data, experts say lawmakers first move should be attacking the information gap."44 The magazine examines a number of tort reform claims as quoted by elected officials, the insurance industry, plaintiffs' lawyers and others, and then examines the source cited for each claim. With every claim cited, the article highlights faulty premises, faulty data, or both, and concludes that the current debate is little more than a public relations war founded on unreliable data. With that in mind, three reports are briefly summarized below.

\section{The Towers Perrin Report}

Within certain interest groups, especially insurers and businesses, the Towers Perrin Report is the most-often quoted study. Paid for by the insurance industry and based on their data, the report focuses on the costs incurred by insurance companies in annual tort claims. The Report estimates the 2003 tort costs as $\$ 245.7$ billion, or 2.23 percent of the 2003 GDP of $\$ 11$ trillion. Twenty years earlier, the 1983 tort costs were $\$ 64.4$ billion, or 1.82 percent of the 1983 GDP of $\$ 3.5$ trillion. 45 Tort costs as a percentage of GDP has thus increased by .041 of a percentage point over 20 years, and the Report predicts the increase will continue absent continued tort reform legislation. ${ }^{46}$

These figures must be read in light of their methodology, which suggest data errors that would both increase and decrease the estimates. First, costs estimates are limited to the costs incurred by liability insurers, and do not include (1) the public costs of funding the court system; (2) costs to plaintiffs that are not recovered in judgments; (3) costs to defendants not reimbursed by insurance; and (4) perhaps most significantly, private and public costs of tort victims who never pursue their claims for whatever reason. These omissions, of course, reduce the cost estimate significantly.

A second methodology question goes to the Report's use of "incurred losses" rather than "paid losses." Incurred losses reflect both payments and the collective change in insurance reserves as a result

43. See http://www.adr.org.

44. A Simple Case of Complexity, supra note 14.

45. Towers Perrin Report at App. 1A.

46. Id. at 2-4. 
of payments, and thus inflate the payments column. ${ }^{47}$ The Report justifies this by claiming that to measure merely paid claims would understate the true costs because, in order to argue otherwise,

one would have to posit that insurers knowingly set reserves too high. We do not believe this is the case. In fact, some rating agencies believe that current insurance industry reserves are, in total, deficient. ${ }^{48}$

The Report cites no authority for this.

A third methodology question is the Report's use of GDP as an index for measuring American tort costs, a phenomenon which includes foreign parties-both plaintiff and defendant-and foreign insurers. There is no data as to whether foreign parties' participation in American litigation is more or less than their participation in the American economy, but the tort reformers' argument that America is the venue of choice suggests that GDP may be an arbitrarily low index that exaggerates the Report's conclusions.

The tone for the Report is best stated in one of its introductory statements that "[o]ver the last 50 years, tort costs in the U.S. have increased more than a hundredfold." 49 The Report makes no attempt, and in fact does not address, the costs of tort injury at a time when tort victims went largely uncompensated because, among other factors, science and medicine were unavailable to prove the injury. To conclude that it has increased a hundredfold assumes that the "costs" were almost nil before 1950, when in fact much of the damage that drove the development of tort law occurred prior to 1950 , with the costs then being borne by the victims.

\section{The Costs of Contract Litigation}

The National Center for State Courts studied civil trials in a 46 county area, limited to claims regarding contracts or similar agreements such as leases or partnerships. The 46 counties surveyed represent roughly 25 percent of the United States population. There were 2,471 contract-related disputes in those 46 counties in 2001 , and the median award in litigated cases was $\$ 78,627$. The number of

47. $I d$. at 7 .

48. Id. at 7.

49. Id. at 2. The Towers Perrin Report makes no distinction as to what aspects of tort litigation should be reformed. It does have a short disclaimer that the Report should not be read as calling for reforms or representing any particular point of view. The disclaimer is somewhat contradicted by the Report's rhetoric. It notes, for example, that the current trend is class action lawsuits against boards of directors and publicly traded companies which will not abate without "sweeping reform"; the Report offers two examples- "claims against pharmaceutical companies for the alleged ill effects of drugs and actions against food establishments for obesity-related injuries." $I d$. at 3. Once again McDonald's is the straw dog with no mention of claims like those filed against Enron, WorldCom, Tyco and others. So much for objectivity. 
cases $(2,471)$ multiplied by the median award $(\$ 78,627)$ is $\$ 194,287,317$. We can make a crude estimate for the United States by multiplying this total (which represented 25 percent of the United States population) by four, and that total is $\$ 777,149,268$, which is a rough estimate of the cost of contract litigation in the United States for 2001.50

\section{The Census Bureau Report of State and Federal Government Court Costs}

In addition to the decennial census, the United States Bureau of the Census conducts periodic surveys of various matters of public interest ranging from government to private finance to health. In 2004, the Census Bureau published its conclusions regarding the state and federal government costs in operating and staffing their courts. The report was based on data compiled from the Census Bureau's annual surveys of governmental finances and employment, based on a survey sample from the 1997 Census of Local Governments, reporting costs as of the budget year 2001. The sample comprised large units of government in all 50 states which were sampled with certainty and smaller units selected with a probability proportional to the unit's expenditure. The total number of local governments in the finance sample was 7,002, and the number of local governments in the employment sample was 10,574 . The study attempted to measure government expenditures on "judicial and legal services," defined as including all civil and criminal courts and activities associated with courts such as law libraries, grand juries, petit juries, medical and social service activities, court reporters, judicial councils, bailiffs, and probate functions. It also includes the civil and criminal justice activities of the attorneys general, district attorneys, states' attorneys, and their variously named equivalents and corporation counsels, solicitors, and legal departments with various names. It excluded legal units of noncriminal justice agencies, whose functions may be performed by a legal services department in other jurisdictions (such as a county counsel).

The study found $\$ 10.23$ billion in federal judicial and legal expenditures, $\$ 14,444$ billion in state expenditures, and $\$ 15,938$ billion in local expenditures, for a total of $\$ 40.61$ billion. State and local governments spent two percent of their budgets for judicial and legal services-the equivalent of $\$ 132$ per capita. The survey also measured the number of judicial and legal service employees and found 57,953

50. See Robert C. LaFountain \& Neal B. Kauder, The National Center for State Courts, Caseload Highlights: An Empirical Overview of Civil Trial Litigation, Vol. 11 No. 1, available at http://www.ojp.usdoj.gov/bjs/pub/pdf/jeeus01.pdf (February 2005) (last visited June 21, 2005). 
federal employees, 162,982 state employees, and 267,208 local employees, for a total of 488,143 judicial and legal-related employees. ${ }^{51}$

\section{The Costs of Legal Aid and Public Defender Programs}

The FY 2005 budget for the Legal Services Corporation (which funds regional legal aid programs) is $\$ 335$ million, reduced to $\$ 318$ million in President Bush's FY 2006 budget request. ${ }^{52}$ Legal aid funding in civil cases is supplemented by private donations and grants, but those are generally not public funds. Indigent criminal defense is more difficult to tally. Because criminal defense is constitutionally mandated, much of the budget comes from state or local governments. The most recent nationwide survey was in 1982 and is no longer valid. When the United States Justice Department attempted a similar survey in 1999 it ran into insurmountable data collection problems. Two years of efforts produced an estimate of the costs in the nation's 100 largest counties, and included findings that (1) within those counties, $\$ 1.2$ billion was spend in 1999 to handle an estimated 4.2 million cases; (2) this amount is three percent of the total criminal justice expenditures in those counties in 1999 ( $\$ 38$ billion total costs of criminal justice in 100 largest counties; $\$ 65$ billion total cost of criminal justice nationwide); and (3) those 100 counties account for 42 percent of the United States' population, and 44 percent of the population with incomes below the poverty level, and a slight majority of the crimes committed in the United States. ${ }^{53}$

\section{Increase/Decrease Over 20 Years}

There is no reliable studies as to current overall costs, and there is no reason to believe that studies of data from 20 years ago are any more reliable. Accepting the Towers Perrin Report's conclusion that costs to insurers have increased over the past 20 years (which is no doubt true), imposing this conclusion on the entire economy is purely speculative. First, the rise in costs to insurers no doubt includes payments for injuries such as those caused by toxins that were incurred in the past, but only recently borne by the tortfeasor. If the calculation comparing 1984 to now were to include all measures of costs, including the costs to victims who were not compensated until toxictort litigation developed, it is almost impossible to compare one time to another.

A more reliable number, limited to government funding for the federal courts, comes from the Administrative Office of the Federal

51. See U.S. Department of Justice, Bureau of Justice Statistics, Justice Expenditures and Employment in the United States, 200, available at http://www.ojp.usdoj. gov/bjs/pub/pdf/jeeus01.pdf (May 2004) (last visited June 20, 2005).

52. See http://www.nlada.org/Defender/Defender_Public.

53. See id. 
Courts. For fiscal year 1985, Congress appropriated $\$ 1.04$ billion for the federal judiciary. In fiscal year 2005, Congress appropriated $\$ 5.426$ billion, an increase of 422 percent over 20 years, not adjusted for inflation. Similar numbers for state courts are not available.

In spite of the lack of reliable data, it is an easy conclusion that the cost of putting on a lawsuit has increased over the past 20 years because of changes in technology that have created broader discovery opportunities and high-tech demonstrative evidence. Similarly, the costs to state and federal governments of budgeting the courts, prosecutors and public defenders office has also increased over the past 20 years. Congress and a number of state legislatures are, in effect, reducing court budgets by failing to fund them at a rate that will keep pace with demands for more judges, more employees, and more technology. ${ }^{54}$

The studies claiming to measure "justice" costs as a function of the economy are misleading in many ways. One primary flaw is that instead of measuring overall economic impact, the studies merely measure the cost to one segment of the economy and fail to address the admittedly intangible costs of the alternatives. In examining the costs of asbestos litigation, for example, studies point out that the resulting corporate bankruptcies cost 52,000 to 60,000 jobs, but failed to consider now many new jobs were created in the economy by companies manufacturing alternatives. ${ }^{55}$ Anti-tort rhetoric invariably fails to address the economic impact of having no legal remedy, or of the beneficial safety measures that result from tort litigation. But the studies and resulting rhetoric on the consumer and trial lawyer side are also unreliable in many instances. This results in a public policy debate that will generate results based on passion and misinformation.

\section{The Service Providers}

The availability and costs of advocacy, whether done by the party, by an attorney, or by a non-attorney is a third crucial compo-

54. For a discussion of the federal judicial budget crisis, see Cost-Containment Strategy for the Federal Judiciary: 2005 and Beyond, Report of the Executive Committee of the Judicial Conference of the United States, Aug. 12, 2004, approved by the Judicial Conference of the United States, Sept. 21, 2004 (hereinafter Cost-Containment Report). See also James P. George, Jurisdictional Implications in the Reduced Funding of Lower Federal Courts, forthcoming in Volume 25 of The Review of Litigation (2006) and articles cited there. For the same issue with state courts, see Judicial Symposium Issue, 38 Akron L. REv. 551 (2004-05); Chief Justice Wallace P. Carson, Jr., At the Crossroads: Are We Prepared to Dismantle Oregon's 143-Year-Old Court System? 63 Or. St. Bar Bull. 15 (2003); James T. Brennan, Judicial Fiscal Independence, 23 U. Fla. L. REv. 277 (1971); Geoffrey C. Hazzard, et al., Court Finance and Unitary Budgeting, 81 YALE L. J. 1286 (1972); Jonathan Bunge, Congressional Underappropriation for Civil Juries: Responding to the Attack on a Constitutional Guarantee, 55 U. CHI. L. Rev. 237, 238 n. 3 (1988).

55. See A Simple Case of Complexity, supra note 44 at 237. 
nent in measuring the delivery of justice. This section is the most abbreviated from the full report, partly because its contents are more widely distributed than the information in the other sections. Readers wanting the longer version may contact the author.

\section{A. Private Attorneys}

Legal consumers who do not qualify for free or reduced-fee services will have to employ a private attorney. Fee arrangements vary, but include hourly fees and for certain cases, a fixed amount. For a limited category of cases such as personal injury and wrongful death, lawyers charge contingency fees which are based on a percentagevarying from 33 to 50 percent-of the client's recovery after costs are subtracted. The contingency fee makes litigation possible for people who could not otherwise afford it, and accordingly has been praised and condemned. Lawyer advertising has been possible as a constitutional right since 1977,56 and like the contingency fee has been heralded as making services both lower cost and more available, and in turn vilified as promoting litigation. ${ }^{57}$ Lawyer fees are regulated to a limited extent but remain largely a matter of private contract law. ${ }^{58}$ This rule, however, applies only to the attorney-client fee agreement and not to the assessment of attorney fees from another party who is not the client. Thus, if a losing defendant is ordered to pay plaintiff's attorney fees, the general standard is reasonableness, which is more restrictive than the unconscionability standard applied to the attorney-client fee agreement. For these instances, attorneys must prove their charges as part of the claim and courts often reduce the fees awarded. State and federal laws also place limits on attorney fees that must be paid by the losing party. ${ }^{59}$ These explanations and legal

56. See Central Hudson Gas \& Electric Corp. v. Public Service Comm'n of New York, 447 U.S. 557 (1980).

57. Lawyer advertising is regulated by state law, but good examples of that regulation are found in ABA Model Rules 7.1 - 7.3. These rules generally allow the advertising of services through written, recorded or electronic communications including public media, so long as the communication is not false or misleading. A lawyer generally may not, in person or by telephone or real-time electronic contact solicit professional employment from a prospective client when a significant motive is the lawyer's pecuniary gain. Thus, lawyers may advertise but are limited in making personalcontact solicitations. Other limits in some states include barring the use of actors to portray clients, limiting claims of past successes, and barring referral to jury verdicts that were later overturned on appeal or substantially reduced.

58. In general, the only regulation of the attorney-client contracting power is that (1) attorneys must explain, preferably in writing, the basis for the fee and any other charges; (2) the attorney may not make false or misleading representations or omissions about the attorney or the services provided; and (3) fees may not be unconscionable. See ABA Model Rules 1.5(b) \& 7.1.

59. Two examples are the Class Action Fairness Act of 2005, Pub.L. No. 109-2, 119 Stat. 4 (effective Feb. 18, 2005) (limiting attorney-fee recovery for successful plaintiffs' attorneys), and the Federal Tort Claims Act, 28 U.S.C.A. $\$ 2678$ (West 1994), capping plaintiff's attorney fees at twenty percent of the amount of settlement during the pre-litigation administrative process, or twenty-five percent of the judg- 
cites should not compel a conclusion that excessive attorney fees are not an issue in the United States. Local bar organizations routinely have arbitration panels that, without cost, will review client complaints about excessive fees. On a larger scale, economic studies often criticize attorney compensation as one problem in both the cost of legal services, and its unavailability to the middle class client. ${ }^{60}$

\section{B. Legal Aid and Public Defenders}

The United States Constitution's Sixth Amendment guarantees legal counsel in criminal prosecutions. This guarantee has not always been read to require free counsel, but merely the right to have counsel. It now requires appointed counsel for indigents in cases where incarceration is possible. ${ }^{61}$ There is no constitutional requirement for counsel in civil cases. The only legal requirement is found in the Legal Services Corporation Act. ${ }^{62}$

In qualifying cases, free legal help is furnished along three basic systems: (1) the staffed legal aid or public defender model, where attorneys are full-time employees; (2) the private contract model, where individual attorneys or law firms agree to provide some or all of the jurisdiction's indigent attorney work; and (3) the appointed counsel model, where the court assigns attorneys who are then paid by a court or county fund (this is common in criminal defense and rare in civil matters ${ }^{63}$ ). For criminal defense, urban areas tend to use the staffed office model, while in rural areas the assigned counsel model is more common. ${ }^{64}$

Public defenders represent eligible low-income clients in criminal cases, while legal aid attorneys represent both plaintiffs and defendants in a range of civil cases including divorce, child support and custody, landlord-tenant, consumer, and public entitlement such as Social Security and state benefits. Legal aid offices will not accept clients in matters deemed "fee generating", that is, where the claim likely involves a monetary recovery sufficiently large to induce a private attorney to accept the claim on a contingency fee basis. Examples include personal injury/wrongful death claims and civil rights claims for government abuse involving injury or death. The fact that

ment or settlement if suit is filed. Attorneys who exceed these amounts may be charged with a crime punishable by fines up to $\$ 2,000$ and up to one year in prison.

60. See Access to Justice, supra note 26 at 33 (overcompensation of lawyers) and 45-46 (excessive legal fees).

61. See Argersinger v. Hamlin, 401 U.S. 908 (1972). Over three-quarters of felony defendants are poor enough to qualify for court-appointed counsel. See Access to JUSTICE, supra note 26 at 11 .

62. 42 U.S.C.A. § 2996 (West 2003 \& Supp. 2005). See Access to Justice, supra note 26 at 8-9 for a discussion of the right to counsel in civil cases.

63. Courts have the power to appoint private attorneys in civil cases, and lawyers have an ethical duty to accept such cases. See ABA Model Rules 6.1 \& 6.2.

64. See http://www.nlada.org/Defender/Defender_Public. 
a legal aid office offers these services does not mean that it is adequately staffed to handle the demand, and a number of otherwise eligible clients are routinely turned down because of the client overload. Estimates are that less than one-fifth of the needs of eligible clients is met-the Bronx Legal Aid Society, for example, has a two-and-a-half year waiting list for divorces. ${ }^{65}$

Criminal defendants in felony cases and some misdemeanor cases are provided with attorneys, at least for the trial level. Free attorneys may not be available for the appeal, although several public defender offices and law school clinics now do criminal appeal defense. Capital murder cases involving the death penalty, which would dictate the highest need for the assistance of counsel at every level, are sometimes without attorneys, or at least adequately trained attorneys. Professor Rhode cites the misconception that minimallyqualified defense attorneys will at least prevent the innocent from being convicted, and then points out recent post-conviction exonerations through DNA evidence. 66

For the delivery of legal services to low-income people, the primary organization in the United States is the Legal Services Corporation and its regional affiliates. ${ }^{67}$ Other organizations include the National Legal Aid and Defender Association, providing funding for both civil and criminal matters; ${ }^{68}$ the American Bar Association Division for Legal Services, providing funding for civil and criminal matters; ${ }^{69}$ the American Bar Association Division on IOLTA; ${ }^{70}$ IOLTA.org-Leadership for Equal Justice; ${ }^{71}$ state programs, such as the Texas Equal Access to Justice Foundation, which administers funds from IOLTA accounts and other sources. ${ }^{72}$

In spite of these organizations' support, the funds are being cut back. For FY 2006, President Bush recommended funding of $\$ 329$ million, a five percent cut from FY 2005.73 Although the United States has had a federally-funded legal aid system since the time of President Nixon, and many locally funded ones before that, there remains significant opposition to these services, and on multiple grounds including that it increases litigation, that it is inefficient

65. See Access to Justice, supra note 26 at 13, and sources cited there.

66. See id. at 125 .

67. See http://lsc.gov. See also 42 U.S.C. \$§ 2996 et seq. (West 2003 \& Supp. 2005) (the Legal Services Corporation Act).

68. See http://www.nlada.org.

69. See http://www.abanet.org/legalservices/home.html.

70. See http://www.abanet.org/legalservices/iolta/home/html.

71. See http://www.IOLTA.org.

72. See http://www.txiolta.org/about/index/html. In the $1990 \mathrm{~s}$, the conservative Washington Legal Foundation challenged IOLTA's legality but lost in two reviews by the United States Supreme Court. See Phillips v. Washington Legal Foundation, 524 U.S. 156 (1998).

73. See Legal Services Now newsletter, April 15, 2005 at http://www.abanet.org/ legalservices/sclaid/sn.html. 
when compared to cash entitlements through which the poor could choose to pay for legal services or pay for some other commodity, and, of course, that it unjustifiably helps deadbeats. ${ }^{74}$

Legal representation for low income clients is also provided by private volunteers under state and local bar association pro bono programs, ${ }^{75}$ law school legal clinics, ${ }^{76}$ interest groups focused on specific subjects like civil rights, ${ }^{77}$ and to a limited extent by church organizations. ${ }^{78}$ Middle class legal consumers may also have legal-service

74. See ACCESS To JUSTICE, supra note 26 at 10-11 and 58-64.

75. ABA Model Rule 6.1 and the laws of several states encourage, and in some cases require, pro bono practice. Texas law reflects the ABA model rule by making pro bono service voluntary rather than mandatory. Both recommend fifty hours' service a year. In spite of efforts for a mandatory pro bono service as a condition of licensing, only three states-Florida, Maryland, and New Jersey-require pro bono service. See ACCESS to JUSTICE, supra note 26 at 153.

76. Approximately 170 of the 185 accredited law programs have law clinics offering services similar to those of legal aid and public defender offices. The precise number is difficult to pin down, especially in terms of legal services to the poor, because (1) some law school clinics serve middle class people such as business and tax clinics, and (2) some schools offering only "simulated clinical" classes such as trial advocacy that do not serve real clients. The most common services provided are family law matters, criminal defense (some trial, some appellate, some both), consumer, and landlord-tenant. Not-so-common clinies include environmental law, international human rights, immigration law, farmworkers, cyberlaw, criminal prosecution, education law, employment law, and nonprofit organizations/small business, which aren't necessarily geared to the client's income status. See http://www.abanet.org/legalservices/probono/ lawschools.

77. Public interest groups providing legal services tend to fall into two categories: (1) access to justice for low income people, and (2) the vindication of specified civil liberties or other interests. These mostly-privately funded groups are too numerous to list here, but include the American Civil Liberties Union; the Center for Individual Rights; the Christian Legal Foundation; the Community Environmental Legal Defense Fund; the Mountain States Legal Foundation; the National Lawyers Guild; the Native American Rights Fund; the Pacific Legal Foundation; the Pro Bono Institute; the Reporters Committee for Freedom of the Press; the Southeastern Legal Foundation; the Southern Poverty Law Center; Trial Lawyers for Public Justice; and the Washington Legal Foundation. Some larger organizations-those focused more broadly than on legal services-have public interest legal centers. A few examples are the the Consumer Resource Center, Earthjustice, the Landmark Legal Foundation, the Mexican-American Legal Defense and Educational Fund, the National Association for the Advancement of Colored People, the National Resources Defense Counsel, the National Organization of Women, Ralph Nader's Public Citizen; the Rutherford Institute, and the Sierra Club. There are also groups with an international focus, including Amnesty International and Human Rights First.

78. Three examples are Catholic Charities, the United Methodist Committee on Relief, and Church World Service Immigration and Refugee Program, all offering legal help to immigrants, particularly political refugees and undocumented workers. See http://gbgm.umc.org./umcor/refugees.stm; http://www.catholicharitiesusa.org; $\mathrm{http}: / / \mathrm{www}$.churchworldservice.org/immigration. Religious organizations such as the Rutherford Institute fund public interest lawsuits vindicating religious liberties and other issues such as right to life. Other faith-based organizations providing some legal assistance include the Christian Legal Society, Baltimore's Jewish Legal Services, and Ohio Legal Assistance Foundation's Interfaith Legal Services. See Mary Medland, Faith groups to immigrants' defense - Community-based programs spring up to meet legal needs, National Catholic Reporter, available at http://www.jewishla.org/ news $/ \mathrm{html} / 1204$-defense.html (November 12, 2004) (last visited June 20, 2005). 
benefits through their employment. ${ }^{79}$

\section{Conclusion}

Measuring access to justice is as elusive as measuring justice itself. The 47 page report from which this article is drawn merely highlights the more important issues. Studies on access to justice, in various conceptions, fill volumes for popular reading and untold amounts of paper and electronic data for not-so-popular reading, all doing little more in the past 20 years than fuel arguments.

Many questions remain. Is the current tort docket a litigation explosion, or merely the proper application of law to injuries now that medicine and technology can establish causation? Is the Americanized-version of the English law court system efficient in resolving twenty-first century disputes? How much should litigation cost the consumer and the economy? Whatever the dispute-resolution system, how can legal advice and advocacy be made available?

A few answers emerge, unpleasantly. On the tort system, even some critics acknowledge that the run-away jury is a myth. The problem is the nuisance lawsuit, and it exists only because deeppocket defendants are inclined to settle rather than force the plaintiff to face the consequences of pursuing a frivolous claim. On accessible legal help, lower-income Americans have access only to a small number of legal remedies in mostly simple cases. Middle-income Americans, ineligible for government-funded attorneys, have less access. Perhaps most foreboding for access to justice, Congress and some legislatures are attacking the judiciary on jurisdictional, economic and personal grounds.

Americans, particular American lawyers, believe we were born into a system founded on the rule of law. Contemplating globalization, we like to believe the American legal system offers an adversarial model with features worth emulating. Current studies, though ambiguous, undermine those beliefs. To the extent these questions are data driven, we must gather accurate numbers and argue them accurately. Once armed with better information, we must consider where we are and where we need to be. The discussion must occur in our bar associations, in our legislatures, and in international conferences where we can learn, and perhaps have something to offer.

79. Two examples of union benefits including legal services are Union Plus Legal Services, see http://www.unionplus.com/benefits/legal, and the International Brotherhood of Teamsters, see http://org.teamster.org/tbenefits.htm (last visited June 15, 2005). 
